\title{
Turn Taking Strategy to Maintain Women`s Self Image in Peri Kopi Novel Written by Yetti A.K.A
}

\author{
Putri Dian Afrinda \\ STKIP PGRI West Sumatera \\ putridian_afrinda@yahoo.com
}

\begin{abstract}
This paper contains a discussion about the turn taking strategies used by the characters to defend women's self-image in the Peri Kopi novel written by Yetti A.K.A. The purpose of this study is to decribe the story the turn taking strategies used in the novel, and what image of the women, as character, described by the act of taking the turn to speak. Technique of data collection was literature study.This research was descriptive qualitative research. Then, the technique used in collecting the data of this research is literature study. Literature study means that the researcher relate the finding of this study to the sources or literatures used. The sources of this research's data are forms of writing, quotation, contained in the novel entittled Peri Kopi written by Yetti A.K.A
\end{abstract}

Keywords—Turn Taking Strategy, Women`s Self-Image

\section{INTRODUCTION}

The role of a women in community is really imporant because they have asignificant effect for their surroundings. For instance, career women will more responsibility to their work. It strongly shows their identity and characters (self-esteem). Selfimage is a form of self-confidence. A woman in particular is more confident if she knows her strengths and weaknesses. The ratio of numbers between women and men is quite dominated by women. Women are often the object of endless conversation. The world around women is interesting to talk about because women are part of the shape of beauty and women are part of the symbol of weakness. These two opposite sides make women's topics interesting to discuss. As Amir and Manaf said in his research (2007) that in communicating activities, the self-image of the communicator can fall by his own speech or someone else's utterance. On the contrary, self-image of speech actor can be lifted because of appropriate speech acting strategy. To support women in the role and strategic importance, women's strategies should be developed to protect their self-image and self-image in verbal communication activities

In communication activities, every communications perpetrator tries to maintain the 'face' (self-image) itself and the 'face' of others who become the gap in the communication. Due to certain situations, the 'face' or image of the perpetrator of communication may fall or be damaged. The fall of the 'face' or self-image of the communicator can lead to a delay or even a communication failure. Furthermore, the perpetrators of communication in the study called the actor said. Actions that threaten the 'face' of speech actor are called face threatening act (Brown and Levinson, 1978). Furthermore, Brown dm Levinson above explains that one of the actions that threaten the 'face' or that can impose the self-image of the actor is speech act. Because speech acts have the potential to drop the 'face' or damage the self-image of the actor, speech acts need to be equipped with a 'face' or protector of self-image. Appliances that can be used to protect the 'face' or self-image are language politeness. Regarding the behavior of women in verbal communication, Crystal (in Amril and Manaf, 2007) explains that the variety of women's languages is not exactly the same as that of men. The differences are among other things lies in the elements of the sentence structure, word choice, pronunciation, clan politeness. Therefore, the behavior of the language of women, in particular women's strategy, protects the image of themselves and the self-image of others in verbal communication needs to be described, explained and formulated.

Novel or fiction as one form of literary work is very interesting to be studied and much studied by literary connoisseurs especially fiction or novel type. The issue of women is an interesting subject to be studied in literature, especially about the strategy of self-defense of women revealed in literary works. The novel as a reflecting part of life can be used as an example to be able to retrieve the message the author wishes to convey through his work. All things about women creation is interested to observe because women problems usually found in our daily life. This point becomes the basis for the researcher to describe about women in their work or creation.Self-esteem which is observed in this research focuses in main actor.It is about how the women preserue their self-esteem which is contrast with their heart of principle.

Bilari is a female character in the novel Peri Kopi by Yetti A.K.A. He opened a coffee shop and hired several employees there. The experience of a broken heart that he lived enough to give it a lesson. His beloved Riga, captured by his best friend Kinta until they marry and have a daughter. Though Riga expressed an interest in returning to Bilari and parting from Kinta, Bilari was not easy to believe because he did not want the painful event to happen again. As time passes to forget the incident comes another man named Dekas who quite often stopped at his coffee shop. However, Bilari is a woman who holds the principles. Although he began to like Dekas, he never showed his true feelings. He will try to conceal his feelings until he is sure 
that he really loves Dekas and vice versa. This makes it not easy to fall in love and not easy to believe in the opposite sex. The behavior of women such as these figures is very rarely found at this time. Women today are generally like pigeons that are no longer benign. Rather it will be easy to get even willing to surrender to the opposite sex. Such circumstances must be a serious concern so that women can still maintain their image by using a certain strategy.

The intended strategy is a turn taking strategy which in this case quotes Brown and Levinson. Speaking strategies are specific ways or speech-delivery techniques that speakers choose for different purposes and intentions by considering various speech-situation factors. Brown and Levinson (1987) explain that language politeness or language courtesy refers to the concept of face (face). Face is referring to self-image or self-esteem. Advance or self-esteem may fall or be damaged by one's own actions or actions of another. Therefore, face or self-esteem should be kept from falling. The need to take care of the face or price din is yourself and others The wrong one that can drop the face is a speech act. Because speech acts have the potential to drop face, speech or speech acts need to be equipped with a protective device face or protector of self-image, namely language politeness. Still according to (Brown and Levinson, 1987), face or image din can be grouped into two, namely positive face and negative face positive face relates to the will of a person to be judged good or positive. On the contrary, a negative face is related to one's own will to be left free to do as he pleases. Because there are two faces, facial protective equipment in the form of language politeness there are two, namely positive politeness and negative politeness. Positive politeness is done by shortening the social distance between speakers and speakers (ingrroupness). Negative politeness is done by elevating the speakers so that the form of social distance (distancing). All things about women creation is interested to observe because women problems usually found in our daily life. This point becomes the basis for the researcher to describe about women in their work or creation.

\section{METHOD}

This research is content analysis. Hasanuddin WS (2003: 40) explains that the content analysis or research review the contents of its activities to analyze the work of literature is seen as a communication product between the author and the environment. So also with Bungin (2004: 172) said that the content of the analysis related to communication and communication content. That every communication always contains a message in the communication signal, in the form of verbal and nonverbal. Qualitative research by using content analysis is more emphasized to how the symbols that exist in the communication is readable in social interaction, so that the credibility of the researcher becomes very important. Content analysis requires researchers who are able to use their analytical sharpness to knit the phenomenon of communication content into a social phenomenon that is read by people in general (Bungin, 2004: 176). The source of this research data is novel Peri Kopi by Yetti AKA. It is also supported by literature related to the research concerned. It is content analysis because the data gotten based on the content and then analyzed deeply in accordance with the indicators found in source of data.

\section{FINDING AND DISCUSSION}

The image of women is a daily behavior. In theory, the image of women is a form of mental and spiritual images of everyday life that is expressed by women in various aspects. Women have a role based on norms such as women who have an active and passive role and women who have a negative role. The discussion on the following data analysis is based on the strategy according to Brown and Levinson (1987) divides the strategy of telling in two groups: positive and negative self image. Positive self image is related to the will of a person to be judged good or positive. On the contrary, a negative self image is related to one's own will to be left free to do as he pleases. Based on data collected in this study, the heroine in protecting the image of himself using indicator tells strategies based on the opinions Brown and Levinson (1987), among others, are as follows. (1) speak frankly without further ado (BTTB), (2) speak frankly with the niceties of positive politeness (BTDBKP), (3) speak frankly with the niceties of negative politeness (BTDBKN), (4) Recalled Vaguely, and (5) speak in the heart (BDH) or silence. Each of the above mentioned strategies is described one by one in the following order.

1. Self-Defense of Women with a Stretched Strategy Continues Bright Without anykind of Chit Chat

"Aku menerima ajakanmu untuk minum kopi bersama," kata Riga.

"Tadi aku sangat berharap kau tidak membaca pesan itu. Seharusnya pesan itu tidak terkirim."

"Baiklah, lupakan saja"

“Cepatlah pergi. Aku tak menginginkan kau di sini selain sebagai seorang tamu RumpiLalang.” (A.KA, 2017: 162)

The quotation above implies that the opponent speaks frankly without preamble to the speaker. Because the presence of speakers is not desirable opponent said. This strategy is actually to avoid the love that can arise back to the speaker. For that indirectly the opponent said to expel the speaker. Another example of a straightforward, frankly spoken strategy by a female character can be seen in the following quotation.

“Aku tidak suka diatur-atur. Aku punya cara hidup sendiri.” Ujar Bilari tidak senang. (A.KA, 2017: 163). 
The quote shows that the principle of women's assertiveness is directly spoken without further ado. This is done as an attempt to maintain the self-image of women against men from the past who still want her.

... Ia menghembuskan nafas keras. Riga lagi. Apa mau lelaki itu?

“Aku rapat,"suara Bilari dibikin sangat ketus. (A.KA, 2017: 167)

Frankly without further ado can be seen in the above quotation. Speakers frankly with a tone that he is in other activities and do not want to be disturbed.

“Aku tahu kamu marah. Bagaimana cara aku menebusnya?”

"Ya?"

"Kamu masih marah, kan?”

"Benar."

"Apa yang harus lakukan?”

"Kau tidak perlu melakukan apa-apa."

"Lalu?"

"Seperti ini saja."

"Aku mencintaimu."

"Itu cinta masa lalu."

"Sekarang tak bisa lagi?"

"Sulit"

"Kinta?"

"Tidak. Aku tak peduli pada dia."

"Kau bisa tidak peduli pada dia?"

"Kenapa aku harus peduli?"

Riga tertawa, menampakkan gigi-giginya yang rapi dan putih. "Kau memaksakan diri untuk terlihat sinis." ...

"Mungkin aku memang sinis" kata Bilari dengan mimik beku. "Dan aku tak peduli penilaianmu”

Riga tertawa sebentar, "Itu bukan kau," katanya, "kau tak perlu memaksakan diri untuk berbeda." (Yetti, 2017: 189).

The quotation above shows that another example of frankly unceremoniously spoken by a female character to protect her image. A woman who holds firm to the principle of believing that if a man hurt her once then the man will repeat the same thing. The persistence of a woman who has been hurt can make a woman more confident in taking a decision.

“Apa yang kau inginkan dariku?” tanya Bilari. Kalimat itu keluar begitu saja. Melompat dari ruang dalam dirinya yang tak pernah ia duga.

Riga menatapnya lekat-lekat. Amat lekat. Tangan kanannya meraih tangan kiri Bilari. Ia bisa saja menariknya cepat-cepat. Ia memilih membiarkannya, "Berhentilah marah. Hiduplah bersamaku dan kita tua bersama-sama"

"Kenapa kau ingin tua bersamaku?” Bilari memainkan gelas kopi di depannya.

Riga mengambil gelas dari tangan Bilari dan meletakkannya ke meja. Diraihnya tangan Bilari dan digenggam kuat. "Sebab itu impian kita dulu."

"Kau sudah menghancurkan mimpi itu."

"Tolong, jangan menoleh ke belakang, Bil. Kita melihat ke depan."

"Mimpi bagaimana yang ada di depan kita?"

"Kita akan segera tahu”

Bilari memandang lembut ke bola mata Riga, "Apa kita bisa membangun mimpi itu dengan cara menyakiti orang lain?”

Riga diam, "Entalah, Bil. Tapi tanpa ada kamu, aku tetap akan berpisah dari Kinta. Kami sulit tetap bersama. Paling tidak aku menyadarinya sekarang dan sama sekali belum terlambat. Baik untukku maupun Kinta. Aku segera menyelesaikan semuanya." (A.KA, 2017: 189 -192)

A strategy for maintaining women's self-image can be seen in the above quotation. Women in these figures have an active and passive role. Active because trying to always avoid the temptation of a man who had hurt him. By using words that sound cynical, assertive, principled, with the aim that the man is no longer interfere with his life.

"Ini pertanyaan serius, Bil. Kenapa kau memutuskan untuk menungguku di sini?”

"Bukankah seharusnya kau masih marah padaku?"

"Bil, aku tahu sekali kalau aku pasti menemukanmu pukul empat nanti." 
“Aku memang marah padamu,” suara Bilari rasanya sangat kacau. Sementara pikirannya mengambang. "Marah sekali. Rasanya aku akan terus hidup dengan rasa marah ini."

“Kalau kau marah, itu artinya kau belum melepaskan aku. Apa kau tidak tahu itu?” Riga tersenyum puas.

The above quotation proves that between the speaker and the opponent he is frankly straightforward to strengthen, emphasize, explain the meaning of the utterance.

\author{
"Kau merencanakan perselingkuhan?" \\ "Kau terlalu blak-blakan sekarang. Itu bukan kamu. \\ "Sudah lama sekali aku ini memang bukan aku lagi-kecuali beberapa hal tentunya. " (A.KA, 2017: 40)
}

The quotation above is marked by an outspoken speech that proves that the speech is using a politeness strategy spoken frankly without preamble.

2. Self-Defense of Women's Self-Esteemed Strategy with Straightforward Positive Practices

This strategy is used by the speaker to fulfill the desire of the speaker so that everything that is in him is considered good or positive. This strategy is formed by reducing or shortening the social distance between speakers and speakers. This strategy consists of (a) using identity markers as members of the same group, (b) providing reasons, (c) involving speakers and speakers in one activity, (d) seeking agreement, (e) pledging, (f) being optimistic To the speaker, (g) declare mutual help and (h) multiply sympathy to the speaker.

Seeking Agreement

Seeking a deal for self-image protection can be seen in the following example.

“Kau pikir menikah itu main-main, ”gerutu Bilari.

"Aku mencintaimu."

Bilari mengalihkan pandangan matanya ke arah pintu. "Aku penyuka kopi berat, kau tidak. Kau suka gerimis, aku tidak,” kata Bilari.

"Itu bukan masalah,” kata Dekas.

"Aku hanya akan mencintai lelaki penyuka kopi berat dan kami akan minum bergelas-gelas kopi, mencoba banyak jenis kopi pada malam-malam yang panjang. Kami bisa berceita tentang berbagai rasa kopi di belahan dunia ini. Karena itu, aku tak bisa, Dekas, aku menolak." (Yetti, 2017: 205)

The quote above to seal the agreement that can benefit both parties as both speakers and opponents said or mitratuturnya. The meaning of the quote is the refusal of the subtle, with the role of active women. Active here means with full confidence in seeking agreement to express rejection.

Multiply Sympathy to the Speaker

The strategy speaks by multiplying sympathy for speakers for the protection of self-image Can be selected in the following speech example.

"Kau perlu belajar bahwa seseorang tidak akan pernah mengejarmu jika kau yang selalu mengejarnya. Bukan, bukan karena ia tak menyukaimu, tapi karena kau tak memberi kesempatan padanya” (A.KA, 2017: 137).

The use of reasons for the protection of self-image can be seen in the above example. The quotation explains that Bilari gives sympathy to his opponent by giving him an idea of why the man he loves his opponent is crazy about Bilari as a speaker. The reasoning explains that the firmness of a woman's principle is that she should be the target of a man or a man who must be crazy about her not the opposite. The principle he taught to other women as the basic principle of women part of the defense of self-image as a woman.

“Bertemu denganmu, membuat hidupku seketika cerah,” ujar Dekas kalem.

"Kau tidak suka cerah, kau suka gerimis,” sindir Bilari.

"Aku bisa menyukai keduanya."

"Kau mulai mengambang. Mirip daun yang terbang dibawa angin. Kau tidak bisa menentukan akan jatuh di mana.” (Yetti, 2017: 23). 
The above quote uses a positive face politeness strategy. This is because the statements spoken by the female character in the novel is part of the intention that when a man loves a woman, everything he likes will include things he does not like, he will learn to like it.

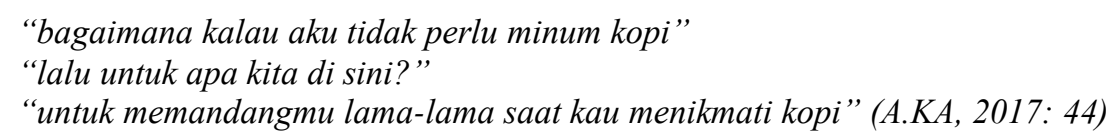

Doubling sympathy for his lawyuture can be seen in the above quotation. Because speakers intent speakers are deliberately looking for the attention of partners said

3. Self-Image Defense with Strategy Speaks Against Light with Negative Despair Prayer

This strategy is used by the speaker to fulfill the desire of the speaker so that everything that is in him is considered good or positive. The BTDBKP strategy is formed by reducing or shortening the social distance between speakers and speakers. This strategy consists of: (a) the question, (b) the use of the fence, (c) the conditional request, (d) the apology, (e) minimizing the burden of the speakers, (f) paying respects, and (g) Abolision of "I" and "We" (h) disclosure, and (i) the statement as a general rule. The realization of BTDBKN's strategy is like the examples of speeches outlined below.

Conditional Request

A form of conditional request to protect the self-image and self-image of others as the following example.

“Tidak," ujar Bilari. “Kau tidak akan pernah bisa memilih, Ga. Kau ingin bersamaku, tapi kau tidak bisa menyakiti Kinta." Bilari melepaskan diri dari Riga. Ia segera masuk ke dalam mobilnya dan meninggalkan tempat itu. (A.KA, 2017: 218)

The above quotation implies that a woman asks for certainty from a man on condition that the man has to choose one of 2 women. Because there is a doubt in the priatersebut then the female character in the novel will behave to leave a man who has no principles in his life.

Minimize Speaking Burden

The minimization of the load on the speaker is done by the speaker by using the expression a little or briefly in the speech, like the following example.

Riga berkata berat "Kau boleh memilih mau datang atau tidak."

"Aku tidak suka diberi pilihan.” (A.KA, 2017: 41)

The quotation above minimizes the load on the opponent he says by giving the option of coming or not. The role of women in this case play an active role. Active to keep rejecting his past male plea.

4. Self-Defense of Women Characters with a Vague Speaking Strategy

This strategy is used by speakers to soften the power of the illocution so that the speech is polite. The BTDBKP strategy is formed by obscuring the meaning of the speaker in the spoken word. These strategies are in the following forms: (a) strong cues and (b) soft cues The realization of a BS strategy is like the examples of speeches outlined below.

Strong

"Kita pulang, ujar Bilari. Ia menoleh keluar. Sebentar lagi hujan pasti turun lebih deras. Setelah ini kita tidak boleh bertemu lagi."

"Setelah ini kita pasti bertemu lagi, Bil," bisiknya (A.KA, 2017: 67)

The speaker's intentions are conveyed vaguely or hidden behind the utterance. A speaker who in this case is a female character, confirms to his opponent that the love story must be ended immediately before any other party is hurt.

“Tidak," ujar Bilari. “Kau tidak akan pernah bisa memilih, Ga. Kau ingin bersamaku, tapi kau tidak bisa menyakiti Kinta." Bilari melepaskan diri dari Riga. Ia segera masuk ke dalam mobilnya dan meninggalkan tempat itu. (Yetti, 2017: 218) 
The above quote implies that the female character demanded a certainty from a man. If there is any doubt in the man then the woman will behave to leave a man who has no principles in his life. The choice alternative used by speakers causes strong signaling effect because it asks the opponent to choose.

5. Self-Defense of Women with Strategies Speak in the Heart or Silence

BDH or silent strategy is the act of "speakers" refraining from verbally expressing their request or appeal to "speakers" because the speech situation is not possible. When compared to other narrative strategies, this silent or silent narrative strategy is the least telling strategy Directly in conveying the message "speakers" to "speakers" because there is not a single word that marks the message "speakers". Nonverbal cues are usually used to help convey the message of "speakers" to "speakers". This strategy of speaking in the heart can be interpreted extensively by the speakers as an alternative choice for "speakers" to refuse "speaker" requests or requests. Here's an example:

"Bagaimana bisa aku setuju untuk bertemu lelaki itu lagi? Pasti ada yang salah denganku, pikirnya. Ini kekeliruan besar. Apa yang kuharapkan dari pertemuan itu? Demi kenangan? Lalu? Tidak ada. Tidak ada 'lalu'. Hanya pertemuan biasa. Setelah itu tak akan ada lagi. Aku janji. Janji. Sekali ini saja lagi. (A.KA, 2017: 38)

Another example

"Seharusnya Dekas berjalan di trotoar itu, pikir Bilari. Ia nyaris meringis merasakan betapa ia merindukan lelaki itu. Ini tentu saja bukan cinta, bantahnya. Ini hanya soal ia yang terbiasa dengan kehadiran lelaki itu di beberapa ruang dalam hidupnya, ruang yang kini terasa lengang, yang sempat diyakininya mampu ia hadapi sebab ia pun telah belajar menerima kekosongan itu sekian waktu. (A.KA, 2017: 213)

Based on the findings of the above research, there are various ways women maintain their self-image from the spoken strategies used. In general, the narrative strategy used in this novel is a straightforward strategy without further ado. This proves that the tendency of a woman to be straightforwardly aims to protect herself and maintain self-image so as not to cause a negative judgment on a woman. Such negative judgment as a woman will easily forgive the man she loves despite being hurt repeatedly. Women will be easily seduced and dogoda so he easily dipersuasif man. Women are symbols of weakness that can be exploited whenever necessary.

\section{CONCLUSION}

Based on the findings of research and data analysis of a discussion that has been done, it can be concluded that in the novel depicted various strategies that can be done by female characters in maintaining the image of herself as a woman. The strategy consists of (1) a straightforward strategy of no-nonsense; (2) a strategy of telling frankly with positive politeness gestures; (3) a straightforward strategy of frank politeness; (4) a strategy of vague speech with strong cues; (5) the strategy of speaking in the heart / silence. The dominant strategy that emerges in the novel is the strategy of telling frankly without further ado. With this strategy, the female character in the novel Peri Kopi written by Yetti A.KA can further explain the meaning of speech against his opponent to cover his lack of self and to maintain the image of himself as a woman.

\section{References}

A.KA, Yetti. (2017). Peri Kopi. Yogyakarta: Ping.

Amir, Amril dan Ngusman Abdul Manaf. (2007). Strategi Wanita Melindungi Citra Dirinya Dan Citra Diri Orang Lain Di Dalam Komunikasi Verbal: Studi di dalarn Tindak Tutur Direktif di dalam Bahasa Indonesia di Kalangan Anggota Kelompok Etnis Minangkabau http://repository.unp.ac.id/121/1/AMRIL\%20AMIR_132_07.pdf (Diunduh 23 juni 2017).

Bungin, Burhan. (2004). Metodologi Penelitian Kualitatif Aktualisasi Metodologis ke Arah Ragam Varian Kontemporer. Jakarta: Rajawali Pers.

Brown, Penelope dan Levinson, Stephen. (1978). "Universal in Language Usage: Politeness Dalam Esther N. Goody (Ed) Question and Politeness: Strategies in Social Interaction. New York: Cambridge University. Halaman 56-324.

Hasanuddin, WS. (2003). Transformasi dan Produksi Sosial Teks Melalui Tanggapan dan Penciptaan Karya Sastra. Kajian Intertekstual Teks Cerita Anggun Nan Tungga Magek Jabang. Bandung: Dian Angkasa Press. 